\title{
分子動力学法による水系電解液電気二重層キャパシタの 界面特性の解析
}

\author{
矢野 振一郎, 古山 通久 ${ }^{*}$ \\ 九州大学 稲盛フロンティア研究センター, ₹ 819-0395 福岡市西区元岡 744 \\ *e-mail:koyama@ifrc.kyushu-u.ac.jp
}

(Received: July 25, 2017; Accepted for publication: November 13, 2017; Online publication: December 25, 2017)

Electric double layer capacitor (EDLC) is a storage device based on the interfacial interaction between electrode and electrolyte. We have conducted molecular dynamics simulations to study the atomistic origin of storage capacity. Electric double layer structures are studied by changing the electric field applied to the electrolyte. Charge density distribution in the electrolyte phase derived on the basis of molecular dynamics simulation is used to discuss the capacitance-voltage characteristics for different electrolyte species.

キーワード : Electric double layer capacitor, Interfacial interaction, Molecular dynamics,

Charge density distribution, Capacitance-voltage characteristics

\section{1 はじめに}

電気二重層キャパシタ(Electric Double Layer Capacitor： EDLC) は電極表面と電解液の界面近傍の相互作用を利用 した蓄電デバイスであり, 分子動力学(MD)の立場から もその容量 -電圧 $(\mathrm{C}-\mathrm{V})$ 特性の解析 [1], 電極の材料, 構 造による高容量化の性能試算 $[2,3]$ などが行われている. EDLCでは電極間に外部電場が無くても, 電極-電解液 界面の張力により Potential of Zero Charge (PZC) と呼ばれ る電位分布が生じる. 蓄電性能の解析に当たっては, こ のPZCの影響を把握することが重要となる，本研究では 平行板グラファイト電極と $\mathrm{LiCl}$ などを溶質とする水系電 解液から成るEDLCを対象に, MD法を用いて外部電場 の有無による電気二重層のナノ構造の変化を調べた.こ れより PZCを求め, EDLCの容量特性への影響を解析し た.また電解液の溶質として $\mathrm{LiCl}$ の他に $\mathrm{NaCl}, \mathrm{CsCl}$ など を取り上げイオン種によって生じる差異についても比較 した.

\section{2 方法}

本解析では, Figure 1に示すようなEDLCのモデルを 用いた. 力場は水分子には SPC/E [4], グラファイトには cvff [5]を適用し, イオン, 水分子間の相互作用はクーロ ンポテンシャルと Lennard-Jones ポテンシャルにより記述
し, Dangら [6]によるパラメータ值を用いた. 外部電場 の強度はグラファイト電極の表面層に与える電荷量 \pm q (e/C- atom, e:電子電荷)により変化させた，MD計算は

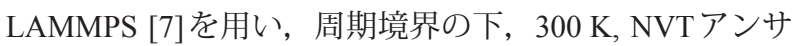
ンブルの条件で行った. 定常状態の解析は, $5 \mathrm{~ns}$ の定常 化の後 $15 \mathrm{~ns}$ のサンプリングにより実施した。 まず電解 液を構成する原子 (水分子の水素原子と酸素原子, およ び電解質のイオン)それぞれについて電荷 $q$ そよって生 じる電極表面に垂直な方向の数密度の分布 $N_{p}(\mathrm{z})$ を求め た. 次にこの数密度分布データを用いて電極間の電位分 布 $V(z)$ を計算した. $V(z)$ は 1 次元の Poisson方程式

$$
\frac{\partial^{2} V(z)}{\partial z^{2}}=-\frac{\rho(z)}{\varepsilon_{0}}
$$

を数值積分することにより求まる $[8]$. ここで $\rho(z)$ は電 解液中の電荷密度分布であり, $\varepsilon_{0}$ は真空の誘電率である. 電解液を構成する粒子 $p$ の空間密度を $N_{p}(\mathrm{z})$, 電荷量を $q_{p}$ とすると

$$
\rho(z)=\sum_{p} q_{p} N_{p}(z)
$$

と表される．最後に電位分布の計算結果から両極間の電 位差 $V$ を求め, EDLC の静電容量 $C_{S}$ を

$$
C_{S}=\frac{q N_{C}}{A_{G} V}
$$


により算出した．ここで $N_{C}$ はグラファイト電極面内の $\mathrm{C}$ 原子の個数, $A_{G}$ は電極のみかけ表面積である.

\section{3 結果と考察}

Figure 2 (a) は $\mathrm{LiCl}$ 水電解液において電場の無い場合 $(\mathrm{q}$ $=0)$ の水分子, 各イオンの数密度分布を計算した結果を 示す．この状態に扔いても, 電極表面の最近傍に水単分 子層とイオンによる層状構造が形成されていることがわ かる.これは電極表面と水溶液界面に生じる界面張力の 影響を反映したものと考えられる. 次に電極の電荷量 $\mathrm{q}$ を変化させて電場の影響を調べた. Figures 2 (b), (c)は, $\mathrm{q}= \pm 0.005 \mathrm{e} / \mathrm{C}$-atomの場合の負極側, 正極側の数密度 分布を示す。同図 (a) と比較すると電場の影響により,
負極側では電極近傍のLiイオン密度のピークが増大, $\mathrm{Cl}$ イオン密度は減少し, 正極側ではその逆の挙動が確認さ れた。次に電解液の溶質を $\mathrm{CsCl}$ に代えて同様の計算を 行った結果を Figure 3 に示す. CsClにおいても電極表面 の最近傍に水分子層とイオンによる層状構造が形成され ているが, Figure 2のLiイオンの分布は水分子層に接し て単峰のピークを持つのに対して,Figure 3のCsイオンは 水分子層の内部と外側にピークを有する双峰性の広がっ た分布になっている. また正極側の $\mathrm{Cl}$ イオンの分布は Figures 2,3いずれの場合も双峰性を示し, この傾向は溶 質の陽イオンによらないこともわかった.

続いて Figures 2,3の各数密度分布に対する電位分布を 計算，比較した．Figure 4 (a) は溶質が $\mathrm{LiCl}$, (b) は $\mathrm{CsCl}$ の 場合について $\mathrm{q}=0, \pm 0.005 \mathrm{e} / \mathrm{C}$-atomでの各数密度分布

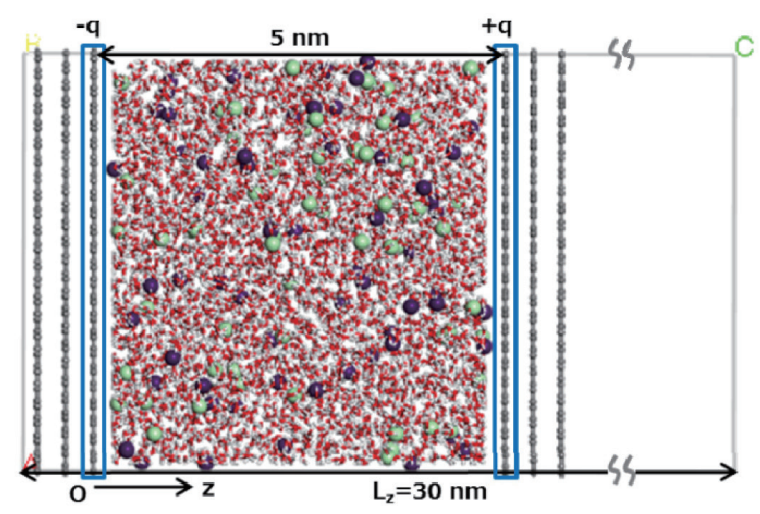

\begin{tabular}{|c|c|c|}
\hline Symbol & Atom & Number \\
\hline$\odot=-$ & Graphite & $960 \times 3$ layers \\
\hline$\odot$ & $\mathrm{Li}^{+}$ & 63 \\
\hline$\odot$ & $\mathrm{Cl}^{-}$ & 63 \\
\hline$>$ & Water & 3,790 \\
\hline \multicolumn{3}{|c|}{ lon cocentration : $0.9[\mathrm{~mol} / \mathrm{L}]$} \\
\hline
\end{tabular}

Figure 1. A typical model employed in the MD simulation.
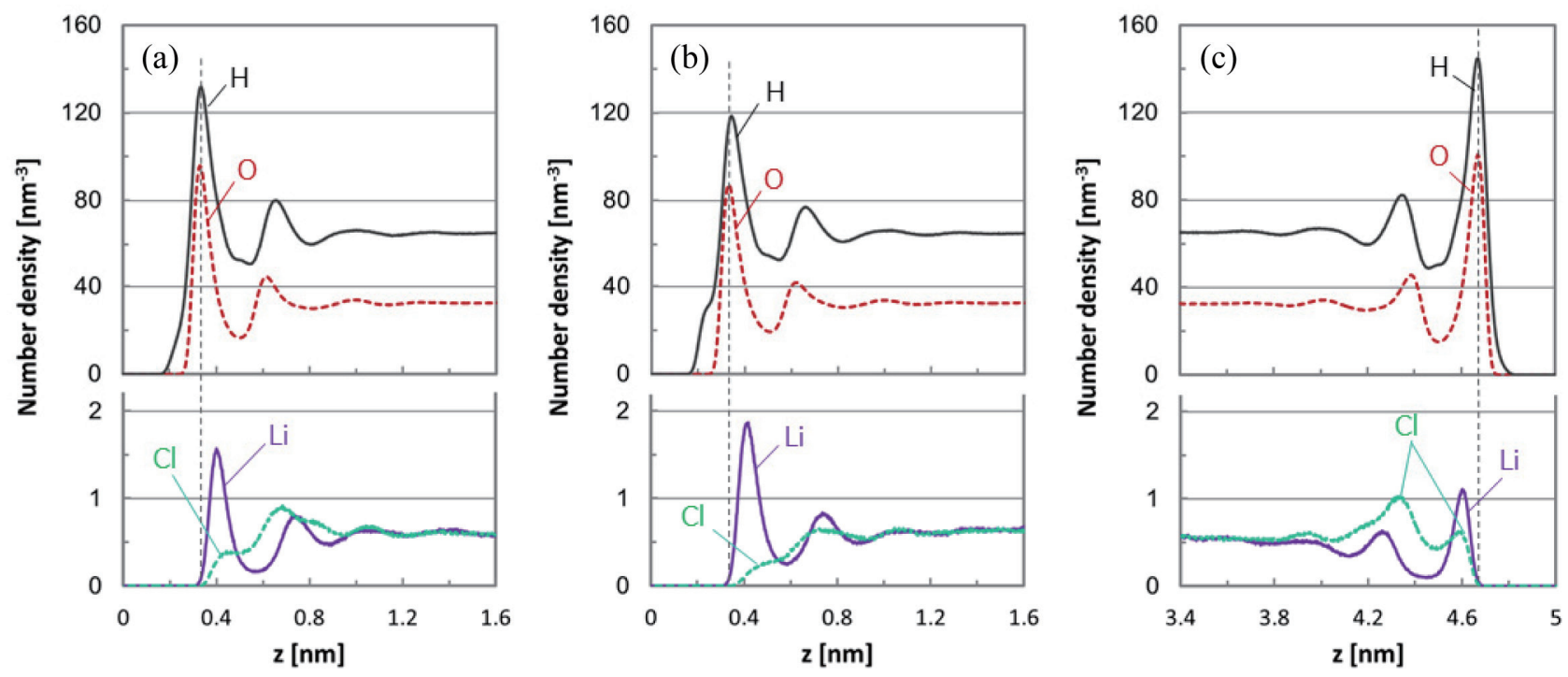

Figure 2. Number density of atoms in $\mathrm{LiCl}$ aqueous electrolyte as a function of distance from the electrode surface with a charge of (a) 0 , (b) -0.005 (cathode), and (c) +0.005 e/C-atom (anode). 

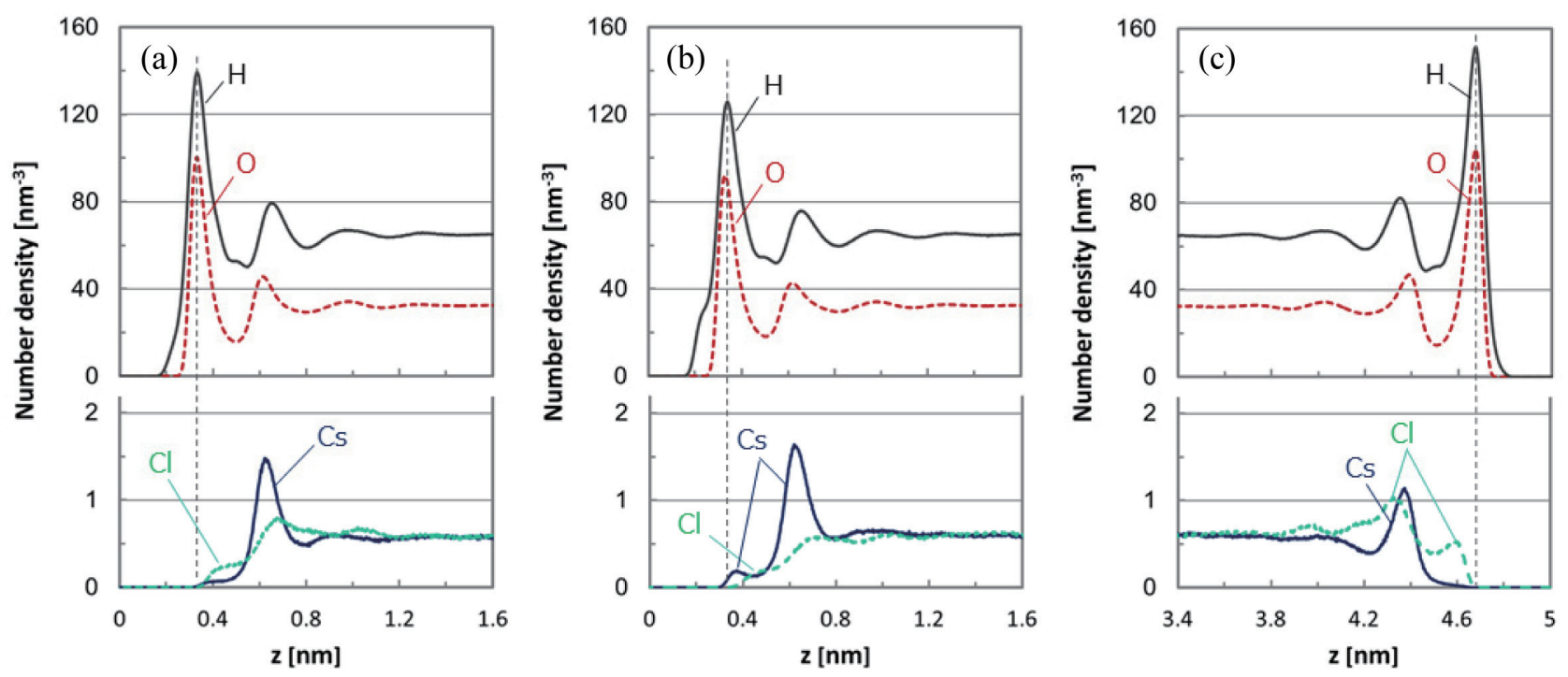

Figure 3. Number density of atoms in $\mathrm{CsCl}$ aqueous electrolyte as a function of distance from the electrode surface with a charge of (a) 0 , (b) -0.005 (cathode), and (c) +0.005 e/C-atom (anode).
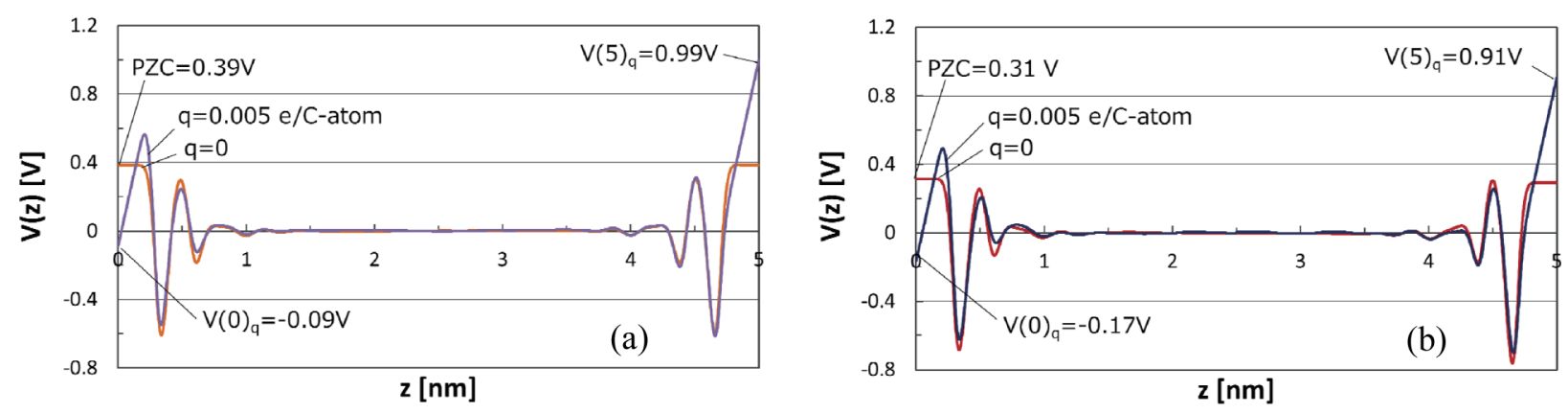

Figure 4. Electrostatic potential distributions for (a) $\mathrm{LiCl}$ and (b) $\mathrm{CsCl}$ aqueous electrolyte with a charge of 0 and \pm 0.005 e/ C-atom.

に対する電位分布を比較した結果を示す．電場の無い $\mathrm{q}=0$ においても電極表面と電解液中央部との間には電位 差PZCが生じ, 各々 $0.39 \mathrm{~V}, 0.31 \mathrm{~V}$ と求まり, PZCはイ オン種によって異なることがわかった. Figure 5 は溶質 の陽イオンによるPZCの差異を比較したものである．陽 イオンのサイズを増すに従って, PZCは0.39 0.31 Vまで 低下することがわかった。 これらの值は水電解液の電位 空 $1.2 \mathrm{~V}$ に対して $33 \sim 25 \%$ 程度となるため, 式(3)による EDLCの静電容量 $C_{S}$ の見積りにはその影響に注意する必 要がある.

Figure 4 より EDLCの中央部 $(\mathrm{z}=1.5 \sim 3.5 \mathrm{~nm})$ には電位 差がほとんど発生しておらず，V (z) 0 Vであることがわ かる. このことから EDLCは正/負電極それぞれの近傍 に個別のEDLCを形成していると見なすことができる. 個々の静電容量を $C_{S c}, C_{S a}$ とすると式(3)に対応して

$$
\begin{aligned}
C_{S c} & =\frac{q N_{C}}{A_{G}[V(0)-P Z C]} \\
C_{S a} & =\frac{q N_{C}}{A_{G}[V(5)-P Z C]}
\end{aligned}
$$

と計算される. Figure 6 は式 (3), (3'), および (3") から求 めた静電容量について溶質の陽イオンによる差異を比較 した結果を示す。それぞれ両極間 : $2.8 \pm 0.1 \mu \mathrm{F} / \mathrm{cm}^{2}( \pm$ $2 \%)$, 負極側 : $6.3 \pm 0.1 \mu \mathrm{F} / \mathrm{cm}^{2}( \pm 1 \%)$, 正極側 $: 5.0 \pm$ $0.1 \mu \mathrm{F} / \mathrm{cm}^{2}( \pm 2 \%)$ の範囲にあり, 溶質の種類による影 響はほとんど認められなかった. Cheng ら [9] は多層構 造のグラフェンを電極に, $\mathrm{LiCl}, \mathrm{NaCl}, \mathrm{KCl}, \mathrm{CsCl}$ を溶質に 用いた水電解液 EDLC の比容量を測定し, 溶質による差 異を比較している. グラフェンの層間が $11 \mathrm{~nm}$ 程度と広 く, サイクリックボルタンメトリーの掃引速度が $2 \mathrm{mV} / \mathrm{s}$ 


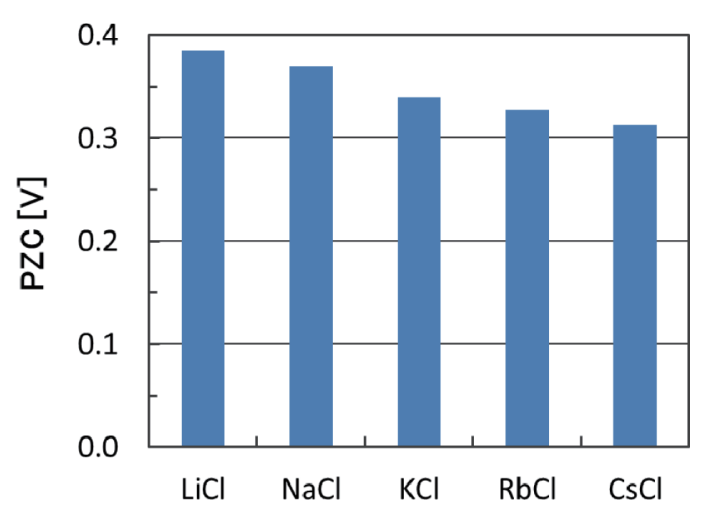

Figure 5. PZCs for different aqueous electrolytes.

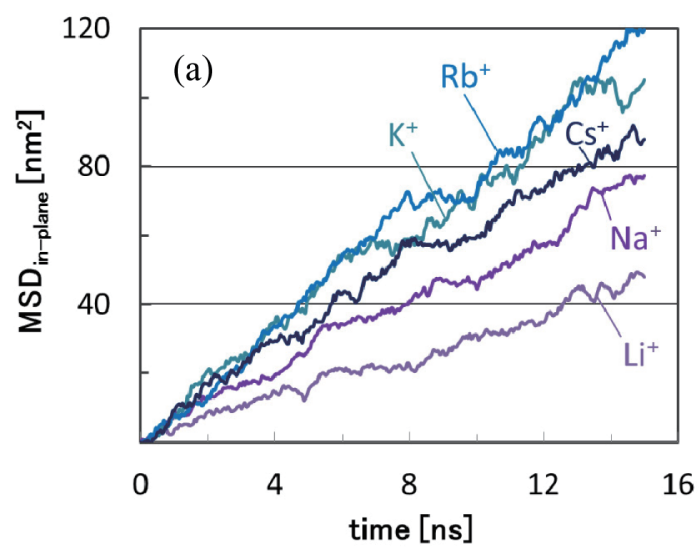

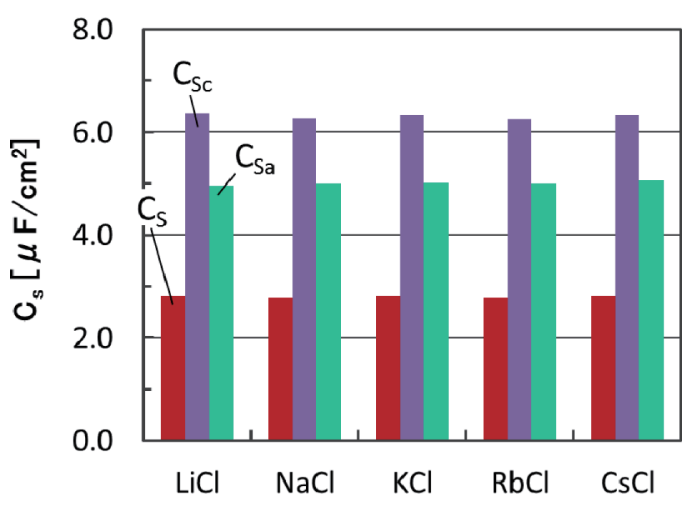

Figure 6. Electrostatic capacitances for different aqueous electrolytes with a charge of \pm 0.005 e/C-atom.

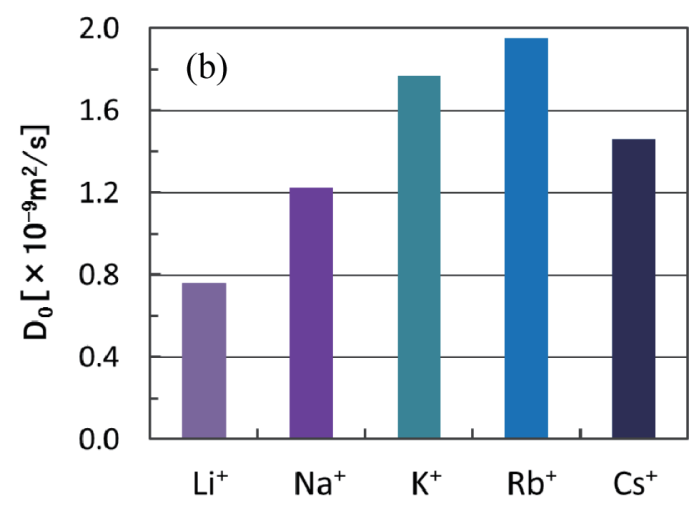

Figure 7. (a) In-plane mean-squared displacement (MSD) for the different cations in aqueous electrolytes and (b) self-diffusion coefficients $\mathrm{D}_{0}$ determined by each slope of MSD curves.

程度と遅い条件下では比容量は溶質によらずほぼ一定と なっており，上記の結果はこれと良く合致している。一 方グラフェンの空隙率が小さく, 掃引速度の速い条件で の比容量は, $\mathrm{LiCl}<\mathrm{NaCl}<\mathrm{CsCl}<\mathrm{KCl}$ の順に増大している. ここで各 EDCL 電解液中の陽イオンの電極面に平行な方 向の平均二乗変位 $\mathrm{MSD}_{\text {in-plane }}$ を求めると Figure 7 (a) に示 すようになり, 同図 (b) はこのときの $\mathrm{MSD}_{\text {in-plane }}$ の勾配 から求めた各陽イオンの自己拡散係数 $\mathrm{D}_{0}$ を示す. $\mathrm{D}_{0}$ は イオン種によって差異が生じ, $\mathrm{Li}^{+}<\mathrm{Na}^{+}<\mathrm{Cs}^{+}<\mathrm{K}^{+}<\mathrm{Rb}^{+}$の順 に増大し, この傾向は上記のイオン種によって差異が生 じる場合の比容量の大小関係と一致している. このとき の比容量は各イオン種の拡散速度に律速して差異が生じ たものと考えられる.

稲盛フロンティア研究センターの研究活動は, 京セラ (株)の支援により行われた. 本研究は, JSTALCAの助 成により行われた. 関係各位に感謝する.

\section{参考文献}

[1] G. Jiang, C. Cheng, D. Li, J. Z. Liu, Nano Res., 9, 174 (2016). DOI:10.1007/s12274-015-0978-5

[2] C. Zhan, Y. Zhang, P. T. Cummings, D. Jiang, Phys. Chem. Chem. Phys., 18, 4668 (2016).

[3] H. Yang, X. Zhang, J. Yang, Z. Bo, M. Hu, J. Yan, K. Cen, J. Phys. Chem. Lett., 8, 153 (2017). DOI:10.1021/acs. jpclett.6b02659

[4] H. J. C. Berendsen, J. R. Grigera, T. P. Straatsma, J. Chem. Phys., 91, 6269 (1987). DOI:10.1021/j100308a038

[5] P. Dauber-Osguthorpe, V. A. Roberts, D. J. Osguthorpe, J. Wolff, M. Genest, A. T. Hagler, Proteins, 4, 31 (1988).

[6] L. X. Dang, J. Am. Chem. Soc., 117, 6954 (1995). DOI:10.1021/ja00131a018

[7] S. Plimpton, J. Comput. Phys., 117, 1 (1995). DOI:10.1006/ jcph.1995.1039

[8] J. N. Sachs, P. S. Crozier, T. B. Woolf, J. Chem. Phys., 121, 10847 (2004).

[9] C. Cheng, J. Uhe, X. Yang, Y. Wu, D. Li, Prog. Nat. Sci Mater. Int., 22, 668 (2012). DOI:10.1016/j. pnsc.2012.11.002 